\title{
Biographical Stages and Information Sources in the Formation of Historical Consciousness
}

\author{
TOMÁŠ KARGER* - JAN KALENDA - JITKA VACULÍKOVÁ
}

Biografické fáze a informační zdroje ve formování historického vědomí

\begin{abstract}
The study inquires into the process of formation of historical consciousness among the population of the Czech Republic. The process is examined in terms of biographical stages and information sources. First, the study draws upon the concept of sensitive period developed by Schuman and Corning. Second, it notes the increasingly mediated nature of socialization to historical consciousness. Data were gathered through a representative survey of the Czech population, with events of February 1948 and August 1968 serving as historical reference points of historical consciousness. Analysis identifies a formative pattern consisting of three stages. The study also identifies typical information sources corresponding to each formative stage. Further analysis employed regression analysis to assess the influence of basic sociodemographic characteristics on the stage in which individuals are socialized.
\end{abstract}

Keywords: historical consciousness; collective memory; sensitive period; socialization; media

DOI: $10.14712 / 23363525.2020 .2$

\section{Introduction}

The practices of memorialization and remembrance have undergone a series of deep transformations. As Paul Connerton [1989] demonstrated, the maintenance of social memory has traditionally been achieved through habitualized body gestures often used when performing rituals. However, modern societies produce conditions that rather facilitate forgetting [Connerton 2009]. The temporality of media is among the key elements constituting the conditions suitable for forgetting. Modern media gradually increase the volume of content and the speed with which it is processed by individuals. Moreover, the tangible substrate of media was transformed or entirely removed with the onset of digital media, making records ever more ephemeral [Connerton 2009: 79-88, 124].

The relationship between communication media and shared images of the past has also been emphasized by Jack Goody, who provides evidence on how written communication was crucial for the creation of "history" as a system of records of past events [Goody 1987: 132]. In following this course, knowledge of the past has been gradually decontextualized to a point when authority is ascribed rather to mediated communication (through books, for example) rather than to personal face-to-face communication [Goody 1987: 163]. As indicated by the growing body of research on the mnemonic aspects of various media [Edgerton 2001; Hoskins 2009b, 2009a; Landsberg 2004; Mayer-Schönberger 2009], the direct transfer of knowledge from generation to generation has been disrupted by

* Tomáš Karger, Research Centre, Faculty of Humanities, Tomas Bata University, Štefánikova 5670, 76001 Zlín. E-mail: karger@utb.cz. 
various other means of information dissemination including schooling, broadcasting, or digital networks.

Currently, the information sources constituent of historical consciousness in the Czech Republic have been explored by Jiří Šubrt and his team [Maslowski - Šubrt 2014; Šubrt 2010; Šubrt - Vinopal 2013; Šubrt - Vinopal - Vávra 2013; Vávra 2013]. ${ }^{1}$ This research endeavor represents a stepping stone for a more focused research into the matter at hand. However, its findings paint a very broad and static picture of production and reproduction of historical consciousness. The findings shed light on information sources on history in general, undifferentiated with regard to particular historical events or stages of individual biographies. To tackle these points of interest, this study aims to account for the use of information sources in the process during which individuals, in the course of their lives, form their historical consciousness and to do so with regard to particular events of modern Czech history.

\section{Theory}

Historical consciousness is a concept that revolves around the relationship between knowledge of the past and other temporal orientations of its bearers. It can be characterized as an interplay between interpretations of the past, perception of the present and expectations of future [Rüssen 2006, 2008]. According to Jiří Šubrt, whose empirical research we take as our starting point, historical consciousness can be analyzed in terms of four components: lived historical experience, ideologies, knowledge produced by historiography, and collective memory (that is, shared representations of the past constitutive of group identity) [Šubrt - Pfeiferová 2010; Šubrt - Vinopal 2010: 10]. By involving both specialized and everyday knowledge of the past, the concept of historical consciousness is meant to be more general - in terms of both scope and abstraction - than that of collective memory, which has been defined in contraposition to historiography already since the times of Maurice Halbwachs [Halbwachs 1992; Olick - Robbins 1998: 110].

As indicated by the Czech historian Miroslav Hroch [Hroch 2014: 52], historical consciousness is constituted as a broad set of unordered and often contradictory memories, facts, myths or other information mediated by various institutions such as school, media, historiography, or simply word-of-mouth. Hroch then sees collective memory as a subset of historical consciousness that is deemed legitimate and worthy of remembering for a given collectivity [Hroch 2014: 52]. In this vein, memory is constituted through mediated dissemination of emotionally charged and mobilizing narratives [Kubišová 2014: 92] selected from the horizons of historical consciousness. On the other hand, historical consciousness is constituted by a circulation of objects and information that is wider in scope and could be likened to a common historical "archive" [Assmann 2008].

Historical consciousness also cuts through the established distinction between communicative and cultural memory by subsuming both everyday communication about recent past experienced by living generations and institutionalized symbolism referring to events constitutive of the collectivity. As Jan Assmann [2008: 110-112], the proponent

1 The sources of information about events of Czech history (particularly the Velvet Revolution in 1989) was briefly examined also by Daniel Kunštát [2010], while Denisa Labischová [2012] limited her inquiry on this matter to the environment of educational institutions. 
of the distinction, indicated, it directly relates to the phenomenon of floating gap. The events of origin are, together with recent events, chiefly among the chapters of past that are collectively maintained [Vansina 1985: 23-24]. In contrast, the gap in between has a low density of events [Zerubavel 2003: 26] that are remembered. This not only points to the fact that certain periods are expected not to be commemorated, but also to the fact that these periods can only be determined with regard to a particular collectivity.

Referential collectivities of historical consciousness and collective memory have traditionally been represented by nation-states, which have been legitimized through naturalized historical narratives since the very beginning of their existence [Anderson 2006; Hobsbawm - Ranger 1983]..$^{2}$ In this study, we intend to focus on age cohorts (and their biographical stages) within a nation-state as referential collectivities of historical consciousness. Although these cohorts may exhibit common patterns with regard to historical consciousness, it is still an open question whether they are bound by a shared "generational consciousness" as argued originally by Karl Mannheim [1952: 299]. Such a question has recently been tackled by Raili Nugin in her research on postsocialist transformation in Estonia, while its various aspects have been explored with regard to postsocialist transformation also by other authors [Aarelaid-Tart 2016; Kõresaar - Jõesalu 2016; Nugin 2015, 2016; Nugin - Jõesalu 2016: 207; Kalmus 2016: 325; Kalmus - Masso - Lauristin 2013: 16; Pozniak 2013]. The common assumption behind this research is that specific historical experiences or specific forms of mediation constitute the differences between generations with regard to the transformation. We will tackle the two analytically distinct sources of historical consciousness further.

While media have always been crucial to historical consciousness, some authors argue that the past is being increasingly mediated by specialized institutions and technologies [Hoskins 2009b] and the content of older media is being re-mediated by newer ones [ErllRigney 2009: 3-4]. Media serve as intermediaries of past events for cohorts that did not experience them directly. Moreover, they also constitute a scaffolding for the memory of those who lived through the mediated events [Hájek - Dlouhá 2011: 51], sometimes to a point when personal memories and media content blend into an undifferentiated image [Sturken 1997: 20]. As a result, it is necessary when studying the formation of historical consciousness to go beyond traditional personal interaction and involve cultural production of objects that are replicated and circulated on a mass scale [Guggenheim 2009: 44; Welzer 2008: 286-288].

In a model that Furnham and Stacey [2016: 9] proposed while studying the formation of children's understanding of the social world, they distinguish between intra-personal, interpersonal and socio-historical aspects of the process. According to the model, socializing content stemming from the socio-historical context is filtered, modified, or negotiated by interpersonal mediation and intra-personal factors, both of which affect the formative process in developmental stages of the individual biography. In other words, the exposure

\footnotetext{
2 In this regard, national holidays and other days of importance have been instrumental in building group identity through organized commemoration. Their importance is made visible in numerous struggles over their selection and definition [for the case of former Czechoslovakia, see eg. Gammelgaard 2011; Miháliková 2005]. Some research indicates that holidays can be seen as pauses in increasingly accelerated time-frames of current societies, allowing for synchronization of activities, attention and presence, but also differentiating various segments of societies based on participation in them [Vihalemm - Harro-Loit 2019]. While interesting in its own right, the role of holidays in establishing communities with shared historical consciousness is out of scope of this study.
} 
to content mediated and interpreted in various ways is anchored in the process of ageing. It is at a certain age that individuals begin to ask, to read, to be schooled, or to be allowed to control their overall media consumption and it is also at a certain age that individuals start exhibiting particular abilities of generalization or inference. As a result, the dynamics of media and personal interaction within individual biographies can be described as a gradual process of growing into the shared historical consciousness.

On the other hand, age cohorts are also distinctively affected by experiencing historical events as they unfold during their formative years. According to contemporary literature [de Regt et al. 2017; Hart-Brinson 2014; Ma - Kim 2015; Schuman - Corning 2000, 2012, 2017; Tekcan et al. 2017], one of the most significant factors influencing individual biography is the "sensitive period", or the so-called "critical years". It represents a time frame between the 10th and 30th year of life during which the process of formation of historical consciousness is most intense. The experience gathered during this period through various significant events is most likely to produce longitudinal generational effects. Schuman and Corning explain the mechanisms behind this crucial period as follows:

National and world events that occur during the critical years should have a lasting impact on individuals because they are usually the first major national or world events experienced, and therefore serve as a baseline against which later events are compared. Individuals beyond their late 20 s will ordinarily have experienced earlier events that seem to them at least equal or greater in importance, while for those $<10$ years, limited awareness of the world beyond their own family and neighborhood means that larger national and world events are not likely to have registered sufficiently to be retained strongly in later memory. Still earlier events learned about indirectly from school or media (e.g., World War II for young people today) cannot have the same emotional impact regardless of their objective significance. [Schuman - Corning 2017: 521]

To summarize, the formation of historical consciousness involves two interlocking processes. First, individual ageing brings about an increasing scope of information sources that quickly reach beyond the immediate surroundings of the family and the immediacy of the present. Second, a common experience with unfolding events during the sensitive period shapes the understanding of other significant events, future or past. To observe the formation of historical consciousness then means to identify patterns in age cohorts that relate the biographical stages of individual lives with experienced events and information intermediaries. To understand the phenomenon, the stages of individual biographies (not only the overall age) must be linked to the sources of experience and information.

To accommodate this premise, we designed our research instrument specifically to provide evidence not only on the current age and media use of respondents, but also on the age (and media used at that age) at which they established their understanding of the historical events. Furthermore, we chose two historical events as references for our survey questions: 1) August 1968 when the Soviet troops and most of their Warsaw Pact allies invaded Czechoslovakia and 2) February 1948 when the Communist Party assumed control over the government of Czechoslovakia. The events are comparable in their significance for the Czech national history while they also represent events that either almost all respondents had only mediated information about (February 1948) or part of them experienced the event during their youth or adult lives (August 1968). A research design that takes into account biographical stages of formation of historical consciousness and 
compares the evidence for events that were or were not directly experienced allows us to at least partially disentangle the effect of a common historical experience of a cohort from the effect of individual ageing.

\section{Methodology}

While we are generally interested in the role of biographical stages and information sources in the formation of historical consciousness, we attempted to address several specific questions in this study: 1) are we able to identify a typical age of historical consciousness formation in the individual biographies? 2) does the age vary for different age cohorts? 3) which sources of information are characteristic of the formative period? 4) what is the role of direct experience with the historical event vis-à-vis mediated information? We attempt to answer these questions using data from a quantitative survey of the Czech population.

A self-report survey was developed in order to gather data through the CAPI technique (Computer Assisted Personal Interviewing) within Omnibus random data collection that took place in Autumn 2016. Respondents answered questions concerning information on how they gathered information about two significant events of the Czech history mentioned earlier (August 1968 and February 1948). For each of the events, respondents answered questions addressing sources from which they learned about the events for the first time and sources of information that were the most important for them in forming their knowledge of these events. Additionally, the questions also addressed the declared level of knowledge of the events, the age of the respondents when they first got to know about the events and the age when they formed their current understanding of the events.

The research sample included a representative sample of Czech population $(\mathrm{N}=1.008)$. The sample was randomly selected based on quota for gender, age, education, and region of residence. The age of the sample ranged from 15 to 89 years with an average age of 45.3 years $(\mathrm{SD}=17.05) .^{3}$ Most respondents had acquired secondary education either without a school-leaving examination (37.6\%) or with a school-leaving examination (33\%), followed by university (16.2\%) and elementary school graduates (13.2\%). More than half of respondents $(63.4 \%)$ were economically active.

Data preparation was conducted indicating missing values in the data set and multivariate outliers. Since there was no presence of serious missing values Little's Missing Completely at Random tests that justify the use of the EM algorithm for replacing missing values with predicted values was no need to test. Influential multivariate outliers were detected with Mahalanobis distance analysis. All outliers above the critical chisquare value $(p<0.001)$ were removed from further analyses [Field 2005]. Presented analyses were conducted using IBM SPSS Statistics v. 24 including calculation of frequencies and testing of hypothetical hypotheses by conducting Chi-square tests with reported effect size.

\footnotetext{
The ratio between the $482(47.8 \%)$ males with an average age of 44.3 years $(\mathrm{SD}=17.52)$ and the $526(52.2 \%)$ females with an average age of 46.3 years $(S D=16.56)$ included in the study corresponds with the gender structure of the Czech population [CZSO 2017].
} 


\section{Results}

In this section, we will first compare our descriptive analysis of information sources with the findings of the research carried out by Šubrt's team. Then we will provide an analysis focused on biographical stages in order to identify patterns in formation of historical consciousness. Finally, we will employ statistical modeling to test (binary logistic regression) for the influence of basic sociodemographic characteristics on the identified patterns.

By simply looking at the frequencies of particular information sources, we note that our results are consistent with previous research [Vávra 2013: 40] in that school teaching and audiovisual media (TV shows, documentary films or radio broadcasting) are declared most crucial for establishing historical consciousness. In Table 1. we provide a more elaborate overview of information sources that respondents designated either as conveying first information about an event or sources that were most important in establishing their understanding of an event. ${ }^{4}$ The use of information sources is further differentiated with regard to particular events: February 1948, which most of our respondents did not experience during their lifetimes and August 1968, which took place in the course of life of a significant portion of respondents.

Table 1: Sources of information about February 1948 and August 1968

\begin{tabular}{lrrrrrrrr}
\hline & \multicolumn{4}{c}{ First sources } & \multicolumn{3}{c}{ Important sources } \\
\cline { 2 - 9 } Sources of information & \multicolumn{2}{c}{1948} & \multicolumn{2}{c}{1968} & \multicolumn{1}{c}{1948} & \multicolumn{1}{c}{1968} \\
\cline { 2 - 9 } & \multicolumn{1}{c}{$n_{i}$} & $f_{i}(\%)$ & \multicolumn{1}{c}{$n_{i}$} & $f_{i}(\%)$ & $n_{i}$ & $f_{i}(\%)$ & $n_{i}$ & $f_{i}(\%)$ \\
\hline 1. TV shows & 30 & $\mathbf{3 . 0}$ & 89 & $\mathbf{8 . 8}$ & 160 & $\mathbf{9 . 8}$ & 259 & $\mathbf{1 4 . 8}$ \\
2. Feature movies & 5 & $\mathbf{0 . 5}$ & 8 & $\mathbf{0 . 8}$ & 57 & $\mathbf{3 . 5}$ & 49 & $\mathbf{2 . 8}$ \\
3. Documentary films & 16 & $\mathbf{1 . 6}$ & 17 & $\mathbf{1 . 7}$ & 186 & $\mathbf{1 1 . 3}$ & 194 & $\mathbf{1 1 . 1}$ \\
4. Radio broadcasting & 9 & $\mathbf{0 . 9}$ & 110 & $\mathbf{1 0 . 9}$ & 31 & $\mathbf{1 . 9}$ & 108 & $\mathbf{6 . 2}$ \\
5. Newspapers & & & & & & & & \\
$\quad$ and their attachments & 6 & $\mathbf{0 . 6}$ & 18 & $\mathbf{1 . 8}$ & 35 & $\mathbf{2 . 1}$ & 89 & $\mathbf{5 . 1}$ \\
6. Magazines & 1 & $\mathbf{0 . 1}$ & 2 & $\mathbf{0 . 2}$ & 12 & $\mathbf{0 . 7}$ & 14 & $\mathbf{0 . 8}$ \\
7. Books & 7 & $\mathbf{0 . 7}$ & 3 & $\mathbf{0 . 3}$ & 76 & $\mathbf{4 . 6}$ & 55 & $\mathbf{3 . 2}$ \\
8. School classes & 609 & $\mathbf{6 0 . 4}$ & 337 & $\mathbf{3 3 . 4}$ & 556 & $\mathbf{3 3 . 9}$ & 360 & $\mathbf{2 0 . 6}$ \\
9. Peers & 8 & $\mathbf{0 . 8}$ & 32 & $\mathbf{3 . 2}$ & 23 & $\mathbf{1 . 4}$ & 62 & $\mathbf{3 . 6}$ \\
10. Parents & 179 & $\mathbf{1 7 . 8}$ & 272 & $\mathbf{2 7}$ & 269 & $\mathbf{1 6 . 4}$ & 319 & $\mathbf{1 8 . 3}$ \\
11. Grandparents & 38 & $\mathbf{3 . 8}$ & 26 & $\mathbf{2 . 6}$ & 100 & $\mathbf{6 . 1}$ & 70 & $\mathbf{4 . 0}$ \\
12. Other family members & 14 & $\mathbf{1 . 4}$ & 46 & $\mathbf{4 . 6}$ & 26 & $\mathbf{1 . 6}$ & 61 & $\mathbf{3 . 5}$ \\
13. Internet & 2 & $\mathbf{0 . 2}$ & 3 & $\mathbf{0 . 3}$ & 46 & $\mathbf{2 . 8}$ & 56 & $\mathbf{3 . 2}$ \\
\hline 14. Don't know & 84 & $\mathbf{8 . 3}$ & 45 & $\mathbf{4 . 5}$ & 73 & $\mathbf{4 . 5}$ & 50 & $\mathbf{2 . 9}$ \\
\hline
\end{tabular}

Note: $n_{i}=$ absolute frequency; $f_{i}(\%)=$ relative frequency $(\%)$

4 It is important to note that while respondents could provide only one first source for each of the historical events, they were allowed to provide up to three most important sources. However, the total number or responses ( 1600 for February 1948 and 1746 for August 1968) indicates that the respondents did not make use of the option too often. 
There are also significant differences in comparison to the previous research results. For example, the role of family members (aggregating parents, grandparents and other family members) is much more significant in our results. This could be explained by framing the survey questions with particular historical events that took place during the lifetime of respondents or their older relatives. In contrast, the questions in Šubrt's survey were aimed at sources of information about history in general, which points to much older events, not belonging to the biographies of other family members. Another difference that could be explained by a different historical time frame of the survey is the high frequency with which radio broadcasting was selected as the first source of information about the events of August 1968. Given that radio receivers were present in many households at the time and that radio broadcasting monitored the events as they unfolded [Končelík - Večeŕa Orság 2010: 190], it seems plausible that the spike in our data is caused by respondents who listened to the broadcast. A similar claim could be made with regard to television broadcasting as a first source of information about August 1968.

Our results also provide more granularity with regard to the roles various information sources play in formation of historical consciousness. For instance, the Internet has already come out as an ambivalent source of information in Šubrt's research, having significant portions of respondents (characterized by age and education) that declare not using it at all for the purposes at hand [Vávra 2013: 41]. Our survey question was formulated specifically to filter out the content that originated in other media and is re-mediated by the Internet (see Appendix I.). The resulting findings suggest that without re-mediated content, the Internet is not very significant with regard to formation of historical consciousness. Furthermore, it seems that audiovisual media are not playing the role of first sources with regard to events that the respondents did not live through, while at the same time, they are seen as important sources of information for establishing the understanding of events. On the other hand, school teaching and family members are often declared to both provide first information and affect the formation of a deeper understanding. However, to elaborate and assess these findings, we need to relate the influence of information sources to biographical stages in the formation of historical consciousness.

The two tables below provide an overview of age periods, in which respondents declare to form their best understanding of the events. The tables further relate the age periods with information sources that, according to respondents, contributed most to the formation of their understanding at that time. ${ }^{5}$ Taking the concept of critical period as our reference point, we can aggregate the age periods into three phases: 1) pre-critical period (up to 10 years of age), 2) critical period (11-29 years) and 3) post-critical period (30 years and more). The information sources are aggregated into four groups according to their relatedness to socializing institutions or agents, a categorization that is employed by existing research on historical consciousness [Labischová 2012: 155]. Such aggregation of age periods and information sources allows us to observe the most significant patterns and their variation with regard to the respective historical events.

\footnotetext{
The tables aggregate the results from a two-step multiple choice question, in which respondents were asked to provide up to three information sources which contributed most to their picture of the event. To each information source, they subsequently provided the age at which they used it.
} 
In both cases, most responses indicate the formation of understanding during the critical period between the age 11 and 29 (64.18\% in the case of February 1948 and $73.33 \%$ in the case of August 1968). Taking a closer look at the data, the age period to which most responses point is situated between the age 11 and 15, when senior classes of elementary school are attended. This age interval represents an early phase of the critical period, during which the formal educational system is most influential. Within this age period, school attendance plays a crucial role with regard to knowledge of the two events $(26.78 \%$ in the case of February 1948 and $15.68 \%$ in the case of August 1968). The second most frequently indicated is the pre-critical period. Its role is more significant with respect to February 1948 as $30 \%$ of responses indicate formation of understanding at the age of less than 10 ( $8 \%$ were even less than 6 years old). The same holds for almost $20 \%$ of responses in the case of August 1968. Only a very small part of responses is to be found after the critical period (5.53\% in the case of February 1948 and 7.25\% in the case of August 1968).

Table 2: Age periods and corresponding sources in formation of knowledge about the events of "February 1948"

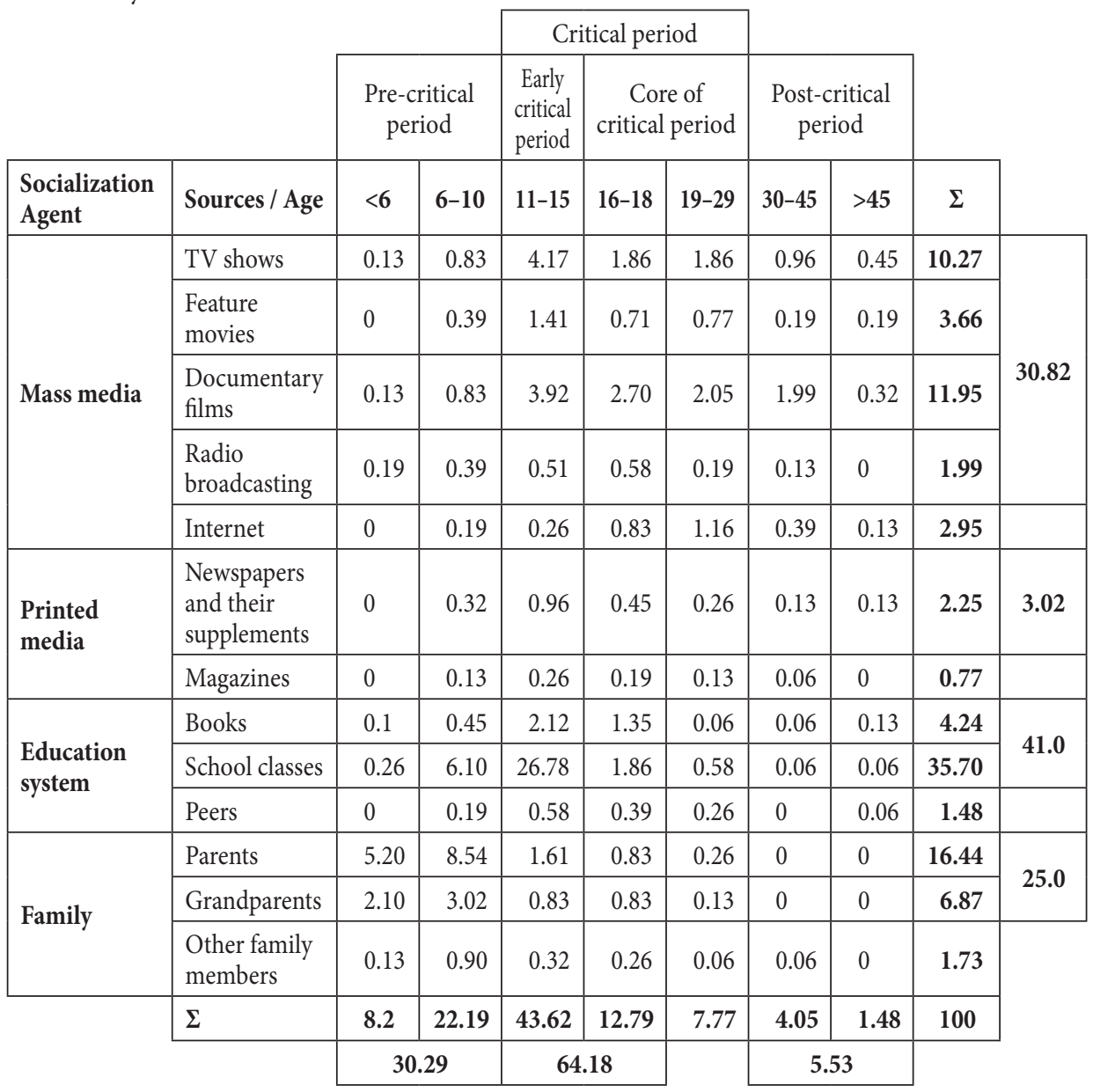


Table 3: Age periods and corresponding sources in formation of knowledge about the events of "August 1968"

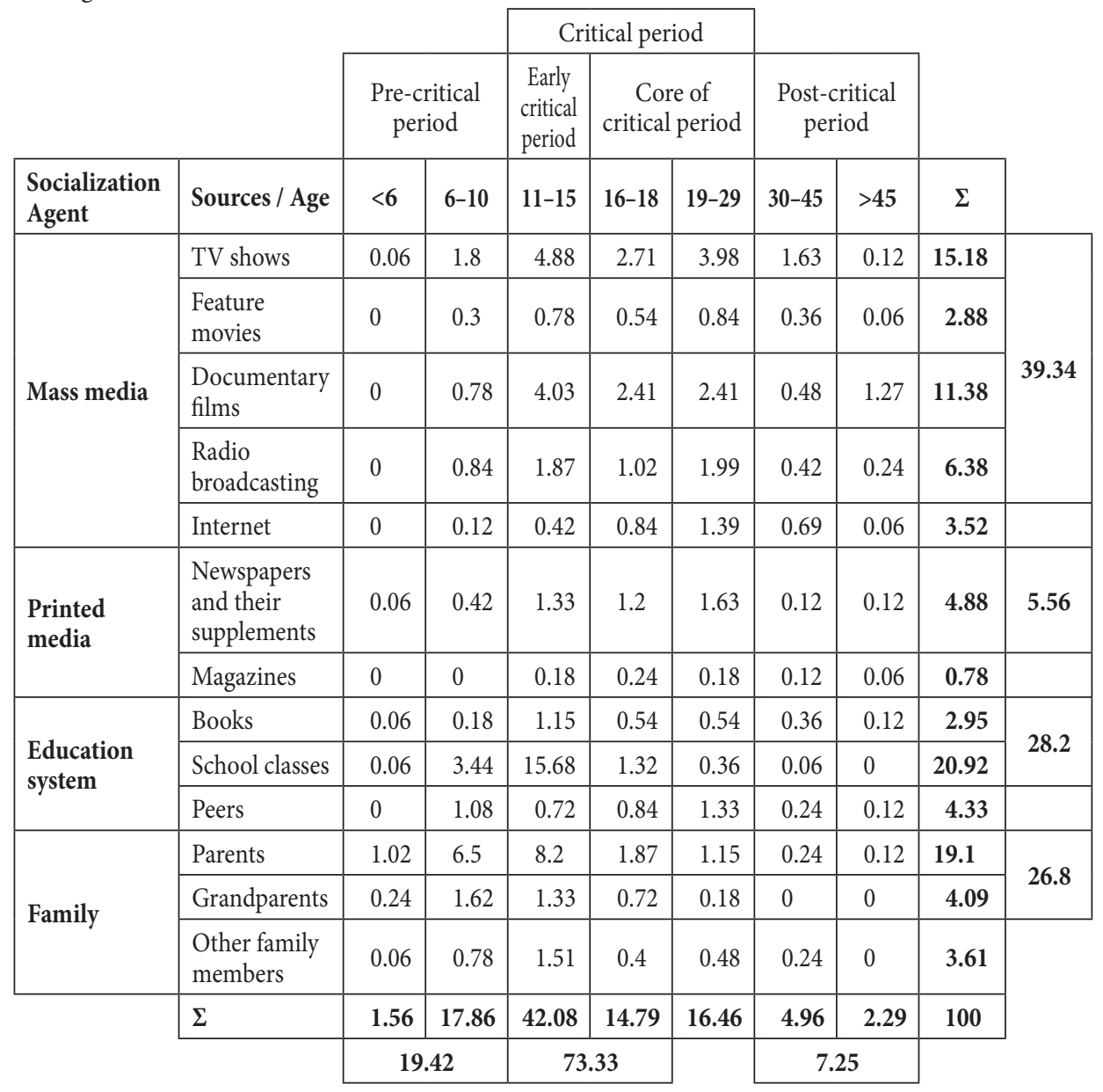

Note: Results in percentage

Looking further, we might observe that the influence of various information sources in the respective age periods is structured similarly for both events, forming an overall staged pattern. In the pre-critical period, family members (mainly parents) are the most influential sources of information. Almost $20 \%$ of responses declared this influence as most significant for their understanding of February 1948. In the case of August 1968, there are $10 \%$ of responses declaring this. The beginning of critical period brings the influence of a variety of other sources. Between the ages 11 and 15, the dominant source is the formal educational system, aggregating the influences of teaching, peers, or books and textbooks. A significant portion of responses indicates the formation of understanding in this period with the help of mass media. In another phase of the critical period (16-29 years), the role of formal education gradually vanes (it accounts for $4-5 \%$ of all responses). The 
understanding formed at this age is informed predominantly by mass media such as television and radio broadcasting or the press. Around 12\% of responses regarding February 1948 can be found at the intersection of this age and the aforementioned sources. With regard to August 1968, the number reaches $18 \%$ of all responses.

The results of the above analysis are further validated when we look at the relationship between information sources and the current age of respondents. In the case of February 1948 (Table 4), the dominant sources (TV shows, documentary films, school classes and parents) are consistent across all age cohorts. It is also true of all cohorts that none of the contains a significant number of individuals who experienced the events directly. In this regard, there is a key difference in the case of August 1968. Here, the oldest age cohort $(60+)$ departs from the established pattern by listing radio broadcasting, printed media or peers as sources forming their understanding of the events. These sources are usually used to inform about events as they unfold and indeed, the cohort is old enough to have experienced the events directly. Moreover, the difference is especially fitting the staged pattern identified above as members of the cohort were 12 or older during the event. At this age, according to the pattern, the sources shift from the family environment to school and media. This is why members of the cohort 45-59 who were largely born before the events, but were younger than 12 reported the same sources as cohorts which were born after the events took place.

Table 4: Age of respondents and corresponding sources in formation of knowledge about the events of "February 1948"

\begin{tabular}{|c|c|c|c|c|c|c|c|}
\hline $\begin{array}{l}\text { Socialization } \\
\text { Agent }\end{array}$ & Sources / Age & $15-29$ & $30-44$ & $45-59$ & $60+$ & $\Sigma$ & \\
\hline \multirow{5}{*}{ Mass media } & TV shows & 0.63 & 3.04 & 3.74 & 2.73 & 10.15 & \multirow{5}{*}{30.44} \\
\hline & Feature movies & 0.51 & 0.95 & 1.27 & 0.89 & 3.61 & \\
\hline & Documentary films & 2.16 & 3.55 & 3.55 & 2.54 & 11.79 & \\
\hline & Radio broadcasting & 0.06 & 0.13 & 0.57 & 1.2 & 1.97 & \\
\hline & Internet & 1.27 & 0.95 & 0.44 & 0.25 & 2.92 & \\
\hline \multirow{2}{*}{ Printed media } & Newspapers & 0.13 & 0.38 & 0.82 & 0.89 & 2.22 & \multirow{2}{*}{2.98} \\
\hline & Magazines & 0.38 & 0.06 & 0.19 & 0.13 & 0.76 & \\
\hline \multirow{3}{*}{ Education system } & Books & 0.89 & 1.33 & 1.33 & 1.27 & 4.82 & \multirow{3}{*}{41.54} \\
\hline & School classes & 8.75 & 9.96 & 9.19 & 7.36 & 35.26 & \\
\hline & Peers & 0.13 & 0.19 & 0.25 & 0.89 & 1.46 & \\
\hline \multirow{3}{*}{ Family } & Parents & 2.41 & 2.85 & 4.5 & 7.29 & 17.06 & \multirow{3}{*}{25.04} \\
\hline & Grandparents & 1.33 & 1.84 & 1.84 & 1.33 & 6.34 & \\
\hline & $\begin{array}{l}\text { Other family } \\
\text { members }\end{array}$ & 0.06 & 0.38 & 0.57 & 0.63 & 1.64 & \\
\hline & $\Sigma$ & 18.71 & 25.62 & 28.28 & 27.39 & 100 & \\
\hline
\end{tabular}

Note: Results in percentage 
Table 5: Age of respondents and corresponding sources in formation of knowledge about the events of "August 1968"

\begin{tabular}{|c|c|c|c|c|c|c|c|}
\hline $\begin{array}{l}\text { Socialization } \\
\text { Agent }\end{array}$ & Sources / Age & $15-29$ & $30-44$ & $45-59$ & $60+$ & $\Sigma$ & \\
\hline \multirow{5}{*}{ Mass media } & TV shows & 1.18 & 3.71 & 5.07 & 5.31 & 15.27 & \multirow{5}{*}{39.27} \\
\hline & Feature movies & 0.83 & 1.3 & 0.59 & 0.18 & 2.89 & \\
\hline & Documentary films & 2.42 & 3.66 & 3.48 & 1.89 & 11.44 & \\
\hline & Radio broadcasting & 0 & 0.18 & 1.47 & 4.72 & 6.37 & \\
\hline & Internet & 1.36 & 1.18 & 0.41 & 0.35 & 3.3 & \\
\hline \multirow{2}{*}{ Printed media } & Newspapers & 0.3 & 0.53 & 1.3 & 3.13 & 5.25 & \multirow{2}{*}{6.08} \\
\hline & Magazines & 0.18 & 0.12 & 0.18 & 0.35 & 0.83 & \\
\hline \multirow{3}{*}{ Education system } & Books & 0.77 & 1.0 & 0.83 & 0.65 & 3.24 & \multirow{3}{*}{28.13} \\
\hline & School classes & 8.02 & 6.8 & 4.89 & 1.53 & 21.23 & \\
\hline & Peers & 0.29 & 0.29 & 0.59 & 2.48 & 3.66 & \\
\hline \multirow{4}{*}{ Family } & Parents & 2.89 & 5.25 & 6.31 & 4.36 & 18.81 & \multirow{3}{*}{26.54} \\
\hline & Grandparents & 1.24 & 1.3 & 1.12 & 0.47 & 4.13 & \\
\hline & $\begin{array}{l}\text { Other family } \\
\text { members }\end{array}$ & 0.18 & 0.59 & 1.18 & 1.65 & 3.6 & \\
\hline & $\Sigma$ & 19.63 & 25.88 & 27.42 & 27.06 & 100 & \\
\hline
\end{tabular}

Note: Results in percentage

\section{Factors Influencing Belonging to Particular Formation Period}

For further exploration of our data, we use binary logistic regression that helps us to identify main factors influencing the likelihood that respondents ${ }^{6}$ form their best understanding of the historical events (February 1948/August 1968) in one of the previously determined formation periods:

(a) The pre-critical period up to 10 years (models M1 and M2);

(b) the early critical period from 11 to 15 years (models M3 and M4);

(c) the late critical period from 19 to 29 years (models M5 and M6).

All models used standard sociodemographic variables (gender, age, education, and size of residence location) as independent variables. The results of relevant statistical tests assessing the significance of constructed models are listed in the tables below (see Tables 6-8.). The results of statistical modelling point to the following findings.

The structure of factors influencing the likelihood that respondents form their best understanding of a historical event in the pre-critical period is very similar with regard to both February 1948 and August 1968s (see Table 6). The variables play the same roles in

6 In order to analyze the data from a multiple-choice question with regard to individual respondents, we opted to include only their first responses. This allows us to account for their most immediate reaction to the question while not omitting too much of the data - as already pointed out, respondents did not opt to provide more than one source too often. 
both models (M1 and M2) and especially age and size of residence location made a unique statistically significant contribution to the models. However, their power of influence varies slightly.

The main difference between them can be found in the strongest predictor. In the M1 model the age category $60+$ results in an odds ratio of 4.6. This indicated that respondents over 60 years were about five times more likely to form their understanding of February 1948 in the pre-critical period than some of the younger age cohorts. However, the power and direction of this category changed in the M2 model. In this case, respondents over 60 years are less likely to form their best understanding of August 1968 before the age of 11 . For every extra year of age, the odds of belonging to the period decrease by a factor of 26 . Moreover, respondents in age between 15 and 59 are generally more likely to belong to a pre-critical period in the model for August 1968 than in model for February 1948. Furthermore, the impact of whether people live in large cities as measured by the number of inhabitants has also increased slightly in the model for August 1968. The odds of belonging to the pre-critical period increase with the growing size of residence location.

Table 6: Regression analysis of factors influencing understanding of the historical events in the precritical period (6-10 years), Models M1 and M2

\begin{tabular}{|c|c|c|c|c|c|c|}
\hline Model & Variable & B & S.E. & Sig. & $\operatorname{Exp}(B)$ & Wald. \\
\hline \multirow{14}{*}{$\begin{array}{l}\text { M1 } \\
\text { Respondents that form } \\
\text { best understanding of } \\
\text { February } 1948 \text { between } \\
\text { 6-10 years }\end{array}$} & Gender & -0.321 & 0.185 & 0.083 & 1.379 & 2.998 \\
\hline & 15-29 years (ref.) & & & 0.000 & & 44.553 \\
\hline & $30-44$ years & 0.065 & 0.336 & 0.848 & 1.067 & 0.37 \\
\hline & $45-59$ years & 0.932 & 0.305 & 0.002 & 2.540 & 9.372 \\
\hline & $60+$ & 1.515 & 0.288 & 0.000 & 4.550 & 27.673 \\
\hline & ISCED 2 (ref.) & & & 0.156 & & 5.229 \\
\hline & ISCED $3 c$ & -0.676 & 0.309 & 0.029 & 0.509 & 4.777 \\
\hline & ISCED 3a,b & -0.371 & 0.305 & 0.225 & 0.690 & 1.475 \\
\hline & ISCED 5,6 & -0.536 & 0.356 & 0.132 & 0.585 & 2.273 \\
\hline & $<4999$ habitants (ref.) & & & 0.000 & & 28.572 \\
\hline & $5000-19000$ & 0.856 & 0.264 & 0.001 & 2.355 & 10.530 \\
\hline & $20000-99000$ & 0.484 & 0.262 & 0.065 & 1.622 & 3.401 \\
\hline & $100000+$ & 1.281 & 0.248 & 0.000 & 3.600 & 26.768 \\
\hline & Constant & -2.639 & 0.343 & 0.000 & 0.71 & 59.348 \\
\hline
\end{tabular}

Statistical significance, $x 2(10, N=1.008)=78.43, p<0.001$. Non-significant Hosmer and Lemeshow test, $x 2(8, N=1.008)=6.91, p=0.55$. Model correctly classifies $82.7 \%$ of cases. 
TOMÁŠ KARGER - JAN KALENDA - JITKA VACULÍKOVÁ Biographical Stages...

\begin{tabular}{|c|c|c|c|c|c|c|}
\hline Model & Variable & B & S.E. & Sig. & $\operatorname{Exp}(B)$ & Wald. \\
\hline \multirow[b]{6}{*}{ M2 } & Gender & 0.173 & 0.189 & 0.360 & 1.189 & 0.837 \\
\hline & 15-29 years ref. & & & 0.000 & & 59.663 \\
\hline & $30-44$ years & 0.235 & 0.279 & 0.401 & 1.265 & 0.707 \\
\hline & $45-59$ years & 1.171 & 0.263 & 0.000 & 3.224 & 19.764 \\
\hline & $60+$ & -1.334 & 0.387 & 0.001 & 0.263 & 11.869 \\
\hline & ISCED 2 (ref.) & & & 0.060 & & 7.422 \\
\hline \multirow{8}{*}{$\begin{array}{l}\text { Respondents that form } \\
\text { best understanding } \\
\text { of August } 1968 \\
\text { between } 6-10 \text { years }\end{array}$} & ISCED $3 c$ & -0.399 & 0.318 & 0.210 & 0.671 & 1.573 \\
\hline & ISCED 3a,b & -0.322 & 0.315 & 0.306 & 0.725 & 1.046 \\
\hline & ISCED 5,6 & -0.991 & 0.384 & 0.010 & 0.371 & 6.664 \\
\hline & $<4999$ habitants (ref.) & & & 0.000 & & 25.502 \\
\hline & $5000-19000$ & 0.708 & 0.276 & 0.010 & 2.031 & 6.589 \\
\hline & $20000-99000$ & 0.724 & 0.254 & 0.004 & 2.062 & 8.122 \\
\hline & $100000+$ & 1.305 & 0.259 & 0.000 & 3.689 & 25.350 \\
\hline & Constant & -2.191 & 3.334 & 0.000 & 0.112 & 43.171 \\
\hline
\end{tabular}

Statistical significance, $x 2(10, N=1.008)=102.07, p<0.001$, Non-significant Hosmer and Lemeshow test, $x 2(8, N=1.008)=4.57, p=0.80$. Model correctly classifies $83.2 \%$ of cases.

The results of statistical modeling for the second formation period (models M3 and M4 in Table 7), the early critical period, are very similar to the previous period age and size of residence location are the most significant variables. In the M3 model, respondents belonging to older age cohorts are less likely to form their understanding of February 1948 in the period from 11 to 15 years when compared to the youngest age cohort (15-29 years). The likelihood of belonging to this formation period decreases with growing age. The influence of age is still significant in the M4 model, but not as much as it was in the previous model. In comparison to older age cohorts, the youngest cohort is still more likely to form understanding of August 1968 in the early critical period. In this regard, respondents aged 15-29 years are three times more likely to form their understanding of August 1968 than respondents aged 30-44 years, five times more likely than respondents aged 45-59 years, and seven times more likely than respondents aged 60+. The likelihood of belonging to this formation period decreases with growing age. 
Table 7: Regression analysis of factors influencing understanding of the historical events in the early critical period (11-15 years), Models M3 and M4

\begin{tabular}{|c|c|c|c|c|c|c|}
\hline Model & Variable & B & S.E. & Sig. & $\operatorname{Exp}(B)$ & Wald. \\
\hline \multirow[b]{6}{*}{ M3 } & Gender & -0.310 & 0.138 & 0.025 & 0.734 & 5.042 \\
\hline & $15-29$ years (ref.) & & & 0.000 & & 29.123 \\
\hline & $30-44$ years & -0.271 & 0.210 & 0.197 & 0.763 & 1.668 \\
\hline & $45-59$ years & -0.673 & 0.208 & 0.001 & 0.510 & 10.460 \\
\hline & $60+$ & -1.009 & 0.206 & 0.000 & 0.365 & 23.962 \\
\hline & ISCED 2 (ref.) & & & 0.070 & & 7.074 \\
\hline \multirow{8}{*}{$\begin{array}{l}\text { Respondents that form } \\
\text { best understanding } \\
\text { of February } 1948 \\
\text { between } 11-15 \text { years }\end{array}$} & ISCED $3 \mathrm{c}$ & 0.142 & 0.238 & 0.551 & 0.1152 & 0.355 \\
\hline & ISCED 3a,b & -0.123 & 0.238 & 0.604 & 0.884 & 0.269 \\
\hline & ISCED 5,6 & -0.380 & 0.270 & 0.160 & 0.684 & 1.971 \\
\hline & $<4999$ habitants (ref.) & & & 0.070 & & 15.901 \\
\hline & $5000-19000$ & -0.671 & 0.195 & 0.001 & 0.511 & 11.813 \\
\hline & $20000-99000$ & -0.105 & 0.180 & 0.001 & 0.901 & 0.337 \\
\hline & $100000+$ & -0.507 & 0.187 & 0.562 & 0.603 & 7.327 \\
\hline & Constant & 1.157 & 0.242 & 0.007 & 0.3179 & 22.799 \\
\hline
\end{tabular}

Statistical significance, $x 2(10, N=1.008)=56.1, p<0.001$. Non-significant Hosmer and Lemeshow test, $x 2(8, N=1.008)=2.33, p=0.97$ Model correctly classifies $60.5 \%$ of cases.

\begin{tabular}{|c|c|c|c|c|c|c|}
\hline Model & Variable & B & S.E. & Sig. & $\operatorname{Exp}(B)$ & Wald. \\
\hline \multirow[b]{6}{*}{ M4 } & Gender & 0.008 & 0.138 & 0.955 & 1.008 & 0.003 \\
\hline & 15-29 years (ref.) & & & 0.000 & & 56.3000 \\
\hline & $30-44$ years & -0.703 & 0.203 & 0.001 & 0.495 & 11.9977 \\
\hline & $45-59$ years & -1.156 & 0.207 & 0.000 & 0.315 & 31.019 \\
\hline & $60+$ & -1.487 & 0.210 & 0.000 & 0.226 & 50.149 \\
\hline & ISCED 2 (ref.) & & & 0.642 & & 1.679 \\
\hline \multirow{8}{*}{$\begin{array}{l}\text { Respondents that form } \\
\text { best understanding of } \\
\text { August } 1968 \text { between } \\
11-15 \text { years }\end{array}$} & ISCED $3 c$ & 0.069 & 0.233 & 0.767 & 1.072 & 0.88 \\
\hline & ISCED $3 \mathrm{a}, \mathrm{b}$ & -0.143 & 0.234 & 0.542 & 0.867 & 3.73 \\
\hline & ISCED 5,6 & -0.042 & 0.269 & 0.876 & 0.959 & 0.24 \\
\hline & $<4999$ habitants (ref.) & & & 0.001 & & 16.806 \\
\hline & $5000-19000$ & -0.572 & 0.197 & 0.004 & 0.564 & 8.400 \\
\hline & $20000-99000$ & -162 & 0.177 & 0.359 & 0.850 & 0.842 \\
\hline & $100000+$ & -684 & 0.193 & 0.000 & 0.505 & 12.511 \\
\hline & Constant & 0.910 & 0.237 & 0.000 & 2.485 & 14.708 \\
\hline
\end{tabular}

Statistical significance, $x 2(10, N=1.008)=80.66, p<0.00$. Non-significant Hosmer and Lemeshow test, $x 2(8, N=1.008)=7.08, p=0.53$, Model correctly classifies $63.1 \%$ of cases. 
Statistical models dealing with factors influencing the formation of historical consciousness in the late critical period (models M5 and M6 in Table 8) point to education as having statistically significant influence. According to the M5 model, the probability of belonging to the period is increasing with every further educational level beyond primary education. In comparison to those who attained primary education (ISCED 2), respondents having secondary education with state exam (ISCED 3a, b) are almost twice as likely to form understanding of February 1948 in the age of 16-29 years; respondents with any form of tertiary education degree (ISCED 5, 6) are 2.6 times more likely to belong to this period. In the M6 model, the level of education is even more important because odds ratios are slightly higher. In the case of August 1968, we can add another important factor - the age of respondents. In the M6 model respondents aged 60+ were about 3.5 times more likely to report acquiring the best information about the events during the late critical period when compared to the youngest cohort included in the survey. However, the cohorts aged 30-44 and 45-59 did not make a unique statistically significant contribution to the model.

Table 8: Regression analysis of factors influencing understanding of the historical events in the late critical period (16-29 years), Models M5 and M6

\begin{tabular}{|c|c|c|c|c|c|c|}
\hline Model & Variable & B & S.E. & Sig. & $\operatorname{Exp}(B)$ & Wald. \\
\hline \multirow{14}{*}{$\begin{array}{l}\text { M5 } \\
\text { Respondents that form } \\
\text { best understanding } \\
\text { of February } 1948 \\
\text { between 16-29 years }\end{array}$} & Gender & 0.300 & 0.162 & 0.064 & 1.349 & 3.443 \\
\hline & 15-29 years (ref.) & & & 0.077 & & 6.847 \\
\hline & $30-44$ years & 0.087 & 0.231 & 0.705 & 1.091 & 0.143 \\
\hline & $45-59$ years & -0.212 & 0.239 & 0.375 & 0.809 & 0.788 \\
\hline & $60+$ & -0.467 & 0.247 & 0.059 & 0.627 & 3.566 \\
\hline & ISCED 2 (ref.) & & & 0.044 & & 8.107 \\
\hline & ISCED $3 c$ & 0.557 & 0.314 & 0.077 & 1.745 & 3.135 \\
\hline & ISCED 3a.b & 0.621 & 0.314 & 0.047 & 1.861 & 3.910 \\
\hline & ISCED 5.6 & 0.948 & 0.340 & 0.005 & 2.581 & 7.770 \\
\hline & $<4999$ habitants (ref.) & & & 0.580 & & 1.963 \\
\hline & $5000-19000$ & 0.215 & 0.223 & 0.336 & 1.240 & 0.925 \\
\hline & $20000-99000$ & -0.034 & 0.213 & 0.874 & 0.967 & 0.025 \\
\hline & $100000+$ & -0.132 & 0.223 & 0.555 & 0.877 & 0.348 \\
\hline & Constant & -1.857 & 0.311 & 0.000 & 0.156 & 35.763 \\
\hline
\end{tabular}

Statistical significance, $x 2(10, N=1.008)=21.63, p<0.01$, Hosmer and Lemeshow test of $x 2(8, N=1.008)=5.39, p=0.72$. Model correctly classifies $77.8 \%$ of cases. 


\begin{tabular}{|c|c|c|c|c|c|c|}
\hline Model & Variable & B & S.E. & Sig. & $\operatorname{Exp}(B)$ & Wald. \\
\hline \multirow{14}{*}{$\begin{array}{l}\text { M6 } \\
\text { Respondents that form } \\
\text { best understanding of } \\
\text { August } 1968 \text { between } \\
16-29 \text { years }\end{array}$} & Gender & -0.061 & 0.148 & 0.683 & 0.941 & 0.167 \\
\hline & 15-29 years (ref.) & & & 0.000 & & 50.991 \\
\hline & $30-44$ years & 0.418 & 0.231 & 0.070 & 1.519 & 3.286 \\
\hline & $45-59$ years & 0.003 & 0.241 & 0.991 & 1.003 & 0.000 \\
\hline & $60+$ & 1.247 & 0.224 & 0.000 & 3.481 & 30.979 \\
\hline & ISCED 2 (ref.) & & & 0.005 & & 12.790 \\
\hline & ISCED $3 c$ & 0.537 & 0.275 & 0.051 & 1.712 & 3.809 \\
\hline & ISCED $3 \mathrm{a}, \mathrm{b}$ & 0.712 & 0.276 & 0.010 & 2.039 & 6672 \\
\hline & ISCED 5,6 & 1.040 & 0.305 & 0.001 & 2.830 & 11.617 \\
\hline & $<4999$ habitants (ref.) & & & 0.436 & & 2.723 \\
\hline & $5000-19000$ & 0.313 & 0.207 & 0.130 & 1.367 & 2.293 \\
\hline & $20000-99000$ & -0.010 & 0.196 & 0.961 & 0.991 & 0.002 \\
\hline & $100000+$ & -0.072 & 0.202 & 0.722 & 1.074 & 0.126 \\
\hline & Constant & -1.973 & 0.291 & 0.000 & 0.0139 & 46.063 \\
\hline
\end{tabular}

Statistical significance, $x 2(10, N=1.008)=68.03, p<0.001$, Hosmer and Lemeshow test, $x 2(8, N=1.008)=13.93, p=0.08$. Model correctly classifies $69.4 \%$ of cases.

\section{Discussion}

The staged pattern identified in our analysis corresponds to some of the classical theories of socialization. In particular, the distinction between primary and secondary socialization as a function of transition from the influence of significant others to that of a generalized other fits the pattern quite well [Berger - Luckmann 1966: 153; Mead 1972: 154]. The primary phase takes place predominantly within the family through socialization by significant others early in the biography of the individual. The secondary phase, on the other hand, takes place later in the biography and involves agents from outside of family such as those found in the school environment or within the media landscape, representing the influence of a generalized other. According to our analysis, the boundary between primary and secondary socialization with regard to formation of historical consciousness is to be found around the 10th year of age.

However, the staged pattern also shows that socialization often begins earlier than the concept of sensitive period would lead us to expect. Given that the broadest age spectrum of the sensitive period begins with the age of 10 , it is the socialization mediated predominantly by family members which undercuts this boundary. Considering the secondary socialization phase involving agents outside of the family environment, the age spectrum defined by the sensitive period seems to hold. This has been validated by relating information sources to the objective age of respondents with regard to August 1968 (Table 5).

Focusing on the other end of the age spectrum, the findings correspond to the concept of sensitive period in that the understanding is generally formed by the 30th year of age. This seems particularly interesting given that the survey questions focused on key events 
associated with the socialist regime, which were redefined after 1989 in the official discourse. Should such a reinterpretation take place also at the individual level, the data would indicate formation of historical consciousness in later stages of life at least for some age cohorts. This finding could indicate a discrepancy between official discourse and informal knowledge to be present already in socialization during socialism. Moreover, February 1948 no longer represented an event of origin after 1989 (and it ceased being celebrated as a national holiday), while August 1968 was overshadowed by November 1989, resulting in low need of reinterpretation at the individual level. This finding could thus be explained by the existence of a floating gap in collective remembering after 1989.

The results of statistical modeling measured the influence of basic sociodemographic factors on the probability of respondents' belonging to one of the identified formative stages. While looking at age, the models largely confirm what can be deduced from the characteristics of the sample. For example, the decreasing likelihood of older age cohorts to belong to the pre-critical stage with regard to August 1968 simply reflects the fact that the event took place when a significant part of the cohorts was older, i.e. they could not be socialized in the pre-critical period, because the event has not happened yet. Perhaps the most interesting factor identified is education, which had similar effect with regard to both historical events. Respondents with higher education are more likely to form their understanding in later stages of life based on their engagement with various media. Education, as it seems, has an effect of prolonging the formative period while bringing in an additional wealth of information sources. The influence of residence location size, on the other hand, is associated more with the events of August 1968. Specifically, it was the strongest predictor of belonging to the pre-critical stage (the larger the residence location, the higher probability of belonging). It seems as if the events were much more impactful in larger cities, causing children to socialize earlier than expected.

\section{Conclusion}

In this article, we aimed to examine the process in which historical consciousness is formed. In particular, we were interested in which information sources respondents use at various stages of their life. Through quantitative analysis, we were able to identify three early life periods that together form a staged pattern: 1) the pre-critical period (age: $>10$, dominant set of sources: family members) 2) the early critical period (age: 11-15, dominant set of sources: school environment); and 3) the late critical period (age: 16-29, dominant set of sources: media environment). To not rely only on declarative statements about when in the course of a lifetime the information sources were used, we also validated the boundary between some of the stages against the current objective age of the respondents. Statistical modeling was employed to further examine the influence of basic sociodemographic characteristics on belonging to any of the identified formative stages. Most interesting in this regard was the role of education, having the effect of prolonging (in terms of age) and widening (in terms of information sources used) the formative process.

The study also has limitations that need to be accounted for. The abstract nature of the identified pattern seems suited for comparative research. However, to a fairly significant degree, the results will depend on the particular historical reference points used. This limits the potential for making general inferences based on comparative surveys, especially 
given the nation-specific character of history. Another limitation of this study can be found in the assumption that respondents remember how they formed understanding of the events. Especially older respondents, having a significant time distance from the period the survey inquired about, may have difficulty remembering. The small age difference that respondents reported with regard to first sources of information as opposed to best sources may indeed indicate conflation and ambiguity. It may even be argued, that instead of the actual usage of information sources, the survey measured internal notions of how and when one should have learned about the events according to respondents. However, this does not negate the identified staged pattern and its association with various sociodemographic characteristics. The structure of the pattern is consistent across age cohorts and changes only with regard to respondents who experienced the events directly. Further research focusing on respondents as they pass through the sensitive period is needed to corroborate the pattern and to clarify its nature.

\section{Bibliography}

Aarelaid-Tart, Aili [2016]. The Soviet Past Through the Lenses of Different Memory Communities. In. Nugin, Raili - Kannike, Anu - Raudsepp, Maaris (eds.). Generations in Estonia: Contemporary perspectives on turbulent times. Tartu: University of Tartu Press, 106-127.

Anderson, Benedict [2006]. Imagined Communities: Reflections on the Origins and Spread of Nationalism. London: Verso.

Assmann, Aleida [2008]. Canon and Archive. In. Erll, Astrid - Nünning, Ansgar (eds.). Cultural memory studies: An international and interdisciplinary hand-book. Berlin: Walter de Gruyter, 97-108.

Assmann, Jan [2008]. Communicative and Cultural Memory. In. Erll, Astrid - Nünning, Ansgar (eds.). Cultural memory studies: An international and interdisciplinary hand-book. Berlin: Walter de Gruyter, pp. 109-118.

Berger, Peter L. - Luckmann, Thomas [1966]. The Social Construction of Reality. A Treatise in the Sociology of Knowledge. London: Penguin Books.

Bourdieu, Pierre - Loïc, Wacquant [1992]. An Invitation to Reflexive Sociology. Cambridge: Polity Press.

Connerton, Paul [1989]. How Societies Remember. Cambridge: Cambridge University Press.

Connerton, Paul [2009]. How Modernity Forgets. Cambridge: Cambridge University Press.

CZSO [December 19, 2017]. Český statistický úřad. Retrieved from: <https://www.czso.cz/csu/czso /ceska-republika-podle-pohlavi-a-veku-2005-2014>.

de Regt, Sabrina - Jaspers, Eva - van der Lippe, Tanja [2017]. Explaining age differences in positive attitudes towards national commemorations: the role of what people commemorate. Nations and Nationalism 23 (4): 726-745.

Edgerton, Gary [2001]. Introduction. Television as Historian: A Different Kind of History Altogether. In. Edgerton, Gary - Rollins, Peter (eds.). Television Histories: Shaping collective memory in the media age. Lexington: The University Press of Kentucky, pp. 1-18.

Erll, Astrid - Rigney, Ann [2009]. Mediation, Remediation, and the Dynamics of Cultural Memory. Berlin: Walter de Gruyter.

Field, Andy [2005]. Discovering Statistics Using SPSS. London: Sage.

Furnham, Adrian - Stacey, Barrie [2016]. Young People's Understanding of Society. London: Routledge.

Gammelgaard, Karen [2011]. The Discursive Battle in 1988 Over the Czechoslovak State Holiday 28 October. Scando-Slavica 57 (1): 48-67.

Goody, Jack [1987]. The Interface Between the Written and the Oral. Cambridge: Cambridge University Press.

Guggenheim, Michael [2009]. Building Memory: Architecture, Networks and Users. Memory Studies 2 (1): 39-53.

Halbwachs, Maurice [1992]. On Collective Memory. Chicago: University of Chicago Press. 
Hart-Brinson, Peter [2014]. Discourse of generations: The influence of cohort, period and ideology in Americans' talk about same-sex marriage. American journal of Cultural Sociology 2 (2): 221-252.

Hájek, Martin - Dlouhá, Marie [2011]. Interpretační kooperace v biografických textech. Biograf 54: 25-41.

Hobsbawm, Eric - Ranger, Terence [1983]. The Invention of Tradition. Cambridge: Cambridge University Press.

Hoskins, Andrew [2009a]. Digital Network Memory. In. Erll, Astrid - Rigney, Ann (eds.). Mediation, remediation, and the dynamics of cultural memory. Berlin: Walter de Gruyter, pp. 91-106.

Hoskins, Andrew [2009b]. The Mediatisation of Memory. In. Garde-Hansen, Joanne - Hoskins, Andrew Reading, Anna (eds.). Save as ... digital memories. New York: Palgrave Macmillan, pp. 27-43.

Hroch, Miroslav [2014]. Pamět a historické vědomí očima historika. In. Maslowski, Nicolas - Šubrt, Jiří (eds.). Kolektivní pamět: K teoretickým otázkám. Prague: Karolinum, pp. 46-65.

Kalmus, Veronika [2016]. The Emergence of the "Digital Generation" in Estonia’s Transition Period. In. Nugin, Raili - Kannike, Anu - Raudsepp, Maaris (eds.). Generations in Estonia: Contemporary perspectives on turbulent times. Tartu: University of Tartu Press, pp. 319-341.

Kalmus, Veronika - Masso, Anu - Laristin, Marju [2013]. Preferences in Media Use and Perception of Inter-Generational Differences Among Age Groups in Estonia: A Cultural Approach to Media Generations. Northern Lights 11 (1): 15-34.

Končelík, Jakub - Večeřa, Pavel - Orság, Petr [2010]. Dějiny českých médií 20. století. Prague: Portál.

Kõresaar, Ene - Jõesalu, Kirsti [2016]. Estonian Memory Culture Since the Post-Communist Turn: Conceptualising Change Through the Lens of Generation. In. Nugin, Raili - Kannike, Anu - Raudsepp, Maaris (eds.). Generations in estonia: Contemporary perspectives on turbulent times. Tartu: University of Tartu Press, pp. 128-158.

Kubišová, Zuzana [2014]. Kolektivní pamět a národní identita. In. Maslowski, Nicolas - Šubrt, Jiř́ (eds.). Kolektivní pamět: K teoretickým otázkám. Prague: Karolinum, pp. 82-111.

Kunštát, Daniel [2010]. Pluralita paměti a komunistická minulost: Česká veřejnost a její reflexe roku 1989 a polistopadového vývoje. Naše společnost (Our Society) 8 (1): 29-39.

Labischová, Denisa [2012]. Factors Shaping the Historical Consciousness of Pupils, Students and Teachers in Czech Schools. The New Educational Review 29 (3): 148-161.

Landsberg, Alison [2004]. Prosthetic Memory: The Transformation of American Rememberance in the Age of Mass Culture. New York: Columbia University Press.

Ma, Kyoung Hee - Kim, Hye Kyung [2015]. Collective Memory and Formation of the "Unconscious" Political Generation: Focusing on the Former Period Baby Boomers in Korea. Development and Society 44 (1): 77-106.

Mannheim, Karl [1952]. Essays on the Sociology of Knowledge. New York: Oxford University Press.

Maslowski, Nicolas - Šubrt, Jiří [2014]. Kolektivní pamèt: k teoretickým otázkám. Prague: Karolinum.

Mayer-Schönberger, Viktor [2009]. Delete: The Virtue of Forgetting in the Digital Age. Princeton: Princeton University Press.

Mead, George Herbert [1972]. Mind, Self, and Society: From the Standpoint of a Social Behaviorist. Chicago: University of Chicago Press.

Miháliková, Silvia [2005]. Political Symbolism of Slovakia: Between the Cross and European Star. Sociológia 37 (6): 529-552.

Nugin, Raili [2015]. The 1970s: Portrait of a Generation at the Doorstep. Tartu: University of Tartu Press.

Nugin, Raili [2016]. Negotiating the Past: Some Issues of Transmission of Memories Among Estonian Young People. Studies of Transition States and Societies 8 (2): 14-30.

Nugin, Raili - Jõesalu, Kirsti [2016]. Narrating Surroundings and Suppression: The Role of School in Soviet Childhood Memories. European Education 48 (1): 203-219.

Olick, Jeffrey K. - Robbins, Joyce [1998]. Social Memory Studies: From "Collective Memory" to the Historical Sociology of Mnemonic Practices. Annual Review of Sociology 24 (1): 105-140.

Pozniak, Kinga [2013]. Generations of Memory in the "Model Socialist Town" of Nowa Huta, Poland. Focaal - Journal of Global and Historical Anthropology 66 (2): 58-68.

Rüssen, Jörn [2006]. Historical consciousness: Narrative, structure, moral function, and ontological development. In. Seixas, Peter (ed.). Theorizing Historical Consciousness. Toronto: University of Toronto Press, pp. 63-85.

Rüssen, Jörn [2008]. History: Narration, Interpretation, Orientation. New York: Barghahn Books. 
Schuman, Howard - Corning, Amy, D. [2000]. Collective Knowledge of Public Events: The Soviet Era form the Great Purge to Glasnost. American Journal of Sociology 105 (4): 913-956.

Schuman, Howard - Corning, Amy, D. [2012]. Generational memory and the critical period: Evidence for national and international events. Public Opinion Quarterly 76 (1): 1-31.

Schuman, Howard - Corning, Amy, D. [2017]. The conversion of generational effects into collective memories. International Journal of Public Opinion Research 29 (3): 520-532.

Sturken, Marita [1997]. Tangled Memories: The Vietnam War, the AIDS epidemic, and the politics of remembering. Berkeley, CA: University of California Press.

Šubrt, Jiří [2010]. Historické vědomí jako predmět předmět badatelského zájmu: Teorie a výzkum. Kolín: Nezávislé centrum pro studim politiky.

Šubrt, Jiří - Pfeiferová, Štěpánka [2010]. Nástin teoreticko-sociologického př́stupu k otázce historického vědomí. In. Šubrt, Jiří (ed.). Historické vědomí jako předmět badatelského zájmu: Teorie a výzkum. Kolín: Nezávislé centrum pro studim politiky, pp. 21-30.

Šubrt, Jiří - Vinopal, Jiří [2010]. K otázce historického vědomí obyvatel České republiky. Naše společnost 8 (1): 9-20.

Šubrt, Jiří - Vinopal, Jiří [2013]. Historické vědomí obyvatel České republiky perspektivou sociologického výzkumu. Prague: Karolinum.

Šubrt, Jiří - Vinopal, Jiří - Vávra, Martin [2013]. The Czechs and Their View of History. European Societies 15 (5): 729-752.

Tekcan, Ali, I. - Boduroglu, Aysecan - Mutlutürk, Aysu - Aktan Erciyes, Asli [2017]. Life-span retrieval of public events: Reminiscence bump for high-impact events, recency for others. Memory and Cognition 45 (7): 1095-1112.

Vansina, Jan [1985]. Oral Tradition as History. Madison: The University of Wisconsin Press.

Vávra, Martin [2013]. Zdroje, z nichž se vytvářejí představy o historii. In. Šubrt, Jiř́ - Vinopal, Jiř́ (eds.). Historické vědomí obyvatel České republiky perspektivou sociologického výzkumu. Prague: Karolinum, pp. 39-45.

Vihalemm, Triin - Harro-Loit, Halliki [2019]. Measuring Society's Temporal Synchronization Via Days of Importance. Time \& Society 28 (4): 1333-1362.

Welzer, Harald. [2008]. Communicative Memory. In. Erll, Astrid - Nünning, Ansgar (eds.). Cultural memory studies: An international and interdisciplinary hand-book. Berlin: Walter de Gruyter, pp. 285-300.

Zerubavel, Eviatar. [2003]. Time Maps: Collective Memory and the Social Shape of the Past. Chicago: University of Chicago Press.

Tomáš Karger is a research fellow at Tomas Bata University in Zlín. He graduated from sociology at Palacký University in Olomouc with a dissertation thesis based on ethnographic research of knowledge networks in free and open-source software development. The dynamics of knowledge production and circulation represents a general research interest which navigates his work in studying digital technologies and the social aspects of memory. Currently, he is focusing on the practices of digital copying and the reproduction of collective memory in the conditions of postsocialism.

Jan Kalenda is an assistant professor at Research Center of the Faculty of Humanities, Tomas Bata University in Zlin. He is active in the fields of sociology and lifelong learning. Within sociology, he focuses on research in historical sociology, social theory, sociology of religion and cultural sociology. He published his research in various monographies and journals among which are: Historical Sociology, Slovak Sociological Review, Asian Social Science Review and Religion and Society in Central and Eastern Europe. He is the author of Formation of European States: Authors, Models and Theoretical Synthesis (2014). 
Jitka Vaculiková studied Social Pedagogy at the Faculty of Humanities, Tomas Bata University in Zlin and obtained her PhD in Pedagogy from Masaryk University in Brno. She is the managing editor of the Sociální pedagogika / Social Education journal and a research fellow of Faculty Research Centre at Tomas Bata University in Zlin. Her research interests are within quantitative research strategies, computer-assisted learning, self-regulation and proactive coping. 


\section{Appendix}

1. How did you first find out about the events of August 1968?
a) From TV broadcasting (e.g. series, reporting)
b) From feature films
c) From documentary films
d) From radio broadcasting
e) From newspapers or their supplements
f) From magazines
g) From books
h) From school teaching
i) From peers
j) From parents
k) From grandparents
1) From other family members
m) From other sources available on the internet
n) I don't know

2. How old were you when you first find out about the events of August 1968 ?
a) Less than 6 years old
b) From 6 to 10 years old
c) From 11 to 15 years old
d) From 16 to 18 years old
e) From 19 to 24 years old
f) I was more than 24 years old
g) I don't know

3. How would you assess your knowledge of the events of August 1968? Would you say that your knowledge of the events is:
a) Very accurate (I know exactly what happened and what it meant)
b) Basic (I have a basic notion of what happened)
c) Rather inaccurate (My knowledge of what happened is vague)
d) None (I don't know what happened)

4. What source of information was most influential in forming your knowledge of August 1968? You can choose up to three.
a) From TV broadcasting (e.g. series, reporting)
b) From feature films
c) From documentary films
d) From radio broadcasting
e) From newspapers or their supplements
f) From magazines
g) From books
h) From school teaching
i) From peers 

j) From parents
k) From grandparents
1) From other family members
m) From other sources available on the internet
n) I don't know

5. How old were you when you gathered information from the sources in the previous question?
a) Less than 6 years old
b) From 6 to 10 years old
c) From 11 to 15 years old
d) From 16 to 18 years old
e) From 19 to 29 years old
f) From 30 to 45 years old
g) I was more than 45 years old
h) I don't know

6. How did you first find out about the events of February 1948 ?
a) From TV broadcasting (e.g. series, reporting)
b) From feature films
c) From documentary films
d) From radio broadcasting
e) From newspapers or their supplements
f) From magazines
g) From books
h) From school teaching
i) From peers
j) From parents
k) From grandparents
1) From other family members
m) From other sources available on the internet
n) I don't know

7. How old were you when you first find out about the events of February 1948 ?
a) Less than 6 years old
b) From 6 to 10 years old
c) From 11 to 15 years old
d) From 16 to 18 years old
e) From 19 to 24 years old
f) I was more than 24 years old
g) I don't know

8. How would you assess your knowledge of the events of February 1948? Would you say that your knowledge of the events is:

a) Very accurate (I know exactly what happened and what it meant) 
b) Basic (I have a basic notion of what happened)

c) Rather inaccurate (My knowledge of what happened is vague)

d) None (I don't know what happened)

9. What source of information was most influential in forming your knowledge of February 1948 ? You can choose up to three.
a) From TV broadcasting (e.g. series, reporting)
b) From feature films
c) From documentary films
d) From radio broadcasting
e) From newspapers or their supplements
f) From magazines
g) From books
h) From school teaching
i) From peers
j) From parents
k) From grandparents
1) From other family members
m) From other sources available on the internet
n) I don't know

10. How old were you when you gathered information from the source in the previous question?
a) Less than 6 years old
b) From 6 to 10 years old
c) From 11 to 15 years old
d) From 16 to 18 years old
e) From 19 to 29 years old
f) From 30 to 45 years old
g) I was more than 45 years old
h) I don't know 